\title{
PENYISIHAN LOGAM BERAT OLEH KARBON AKTIF DAUN ECENG GONDOK PADA LIMBAH CAIR SABLON
}

\author{
Mala Oktaviyana Lussa
}

\author{
Jurusan Teknik Lingkungan, Fakultas Arsitektur Lanskap dan Teknologi Lingkungan, \\ Universitas Trisakti, Jakarta, Indonesia
}

Email korespondensi: mala08215035@std.trisakti.ac.id

\begin{abstract}
ABSTRAK
Penelitian ini bertujuan untuk menyisihkan logam berat menggunakan karbon aktif daun eceng gondok yang teraktifasi. Efek waktu kontak, kecepatan pengadukan dan berat adsorben pada laju adsorpsi diperiksa untuk mencapai efisiensi terbesar dalam proses penyisihan logam berat. Penurunan konsentrasi logam berat dianalisis menggunakan AAS. Optimalisasi parameter penyerapan dilakukan dalam sistem batch menggunakan konsentrasi air limbah mengandung logam berat, konsentrasi adsorben dengan pengaturan waktu kontak, kecepatan pengadukan dan berat adsorben. Hasil penelitian terdahulu lainnya menunjukkan bahwa adsorben daun enceng gondok yang tidak di aktivasi lebih sedikit daya serapnya dibandingkan dengan adsorben yang di aktivasi. Penelitian membuktikan bahwa adsorben terikat sangat efektif untuk menurunkan kadar logam berat dalam air limbah sehingga dapat menjadi alternative metoda pengendalian pencemaran logam berat di perairan yang kompetitif dan ramah lingkungan.
\end{abstract}

Kata Kunci: Daun Eceng Gondok, Adsorpsi, Limbah Cair Sablon, Logam Berat

\section{PENDAHULUAN}

Air merupakan sumber daya alam yang diperlukan untuk kebutuhan hidup manusia, bahkan oleh semua makhluk hidup. Oleh karena itu, sumber daya air harus dilindungi agar tetap dapat dimanfaatkan dengan baik oleh manusia serta makhluk hidup yang lain. Pemanfaatan air untuk berbagai kepentingan harus dilakukan secara bijaksana, dengan memperhitungkan kepentingan generasi sekarang maupun generasi mendatang. Aspek penghematan dan pelestarian sumber daya air harus ditanamkan pada segenap pengguna air.

Saat ini, masalah utama yang dihadapi oleh sumber daya air meliputi kuantitas air bersih yang sudah tidak mampu memenuhi kebutuhan yang terus meningkat dan kualitas air untuk keperluan domestik yang semakin menurun. Maraknya berbagai kegiatan industri di Indonesia berdampak negatif terhadap sumber daya air, antara lain menyebabkan penurunan kualitas air. Kondisi ini dapat menimbulkan gangguan, kerusakan, dan bahaya bagi semua makhluk hidup yang bergantung pada sumber daya air. Oleh karena itu, diperlukan pengelolaan dan perlindungan sumber daya air secara seksama.

Dalam setiap kegiatan produksi, selain menghasilkan suatu produk yang mempunyai nilai tambah, juga menghasilkan limbah, baik limbah padat, cair, maupun gas, termasuk di dalamnya kegiatan industri, dalam hal ini sablon yang menggunakan bahan baku zat warna dan lain-lain dari zat kimia usaha penyablonan. Limbah dari kegiatan penyablonan yaitu berupa limbah cair dari proses pencucian screen, limbah padat (sisa - sisa potongan kain) dan tumpahan dari zat warna/ pewarnaan yang dipakai untuk proses penyablonan.

Limbah yang dihasilkan oleh usaha sablon adalah limbah cair dari hasil proses pencucian, penyemprotan, serta limbah padat yang dihasilkan berupa sisa kain, plastik dan lain-lain. Umumnya limbah cair yang dihasilkan dari usaha sablon berwarna pekat dan 
berbau. Limbah dari proses penyablonan akan mencemari lingkungan jika dibuang langsung ke selokan dan badan air, khususnya pencemaran yang berada pada lingkungan tersebut. Oleh sebab itu perlu dilakukan upaya-upaya pengelolaan limbah cair tersebut.

\section{TINJAUAN PUSTAKA}

\section{Limbah Cair Sablon}

Limbah yang dihasilkan oleh usaha sablon adalah limbah cair dari hasil proses pencucian, penyemprotan, serta limbah padat yang dihasilkan berupa sisa kain, plastik dan lain-lain. Umumnya limbah cair yang dihasilkan dari usaha sablon berwarna pekat dan berbau (Chalid,2008).

Limbah cair sablon termasuk dalam limbah tekstil yang mengandung bahan-bahan yang berbahaya bila dibuang ke lingkungan, terutama daerah perairan. Sebagian besar bahan yang terdapat dalam limbah tekstil adalah zat warna, terutama zat warna sintetik. Zat warna sintetik merupakan molekul dengan sistem elektron terdelokalisasi dan mengandung dua gugus yaitu kromofor dan auksokrom (Dewi, 2009).

\section{Logam Berat}

Membuang limbah yang mengandung logam berat ke lingkungan menjadi masalah utama dalam permasalahan air yang tercemar. Hal ini menimbulkan dampak pada meningkatnya organisme yang mengandung polutan logam berat seperti pada biota laut, karang, dan beberapa keluarga alga atau rumput laut. Hal yang sangat memprihatinkan, konsumsi tinggi sumber makanan laut yang tercemar logam berat oleh manusia merupakan masalah penting bagi kesehatan manusia (Darjito et al 2014). Pencemaran logam berat dapat merusak lingkungan antara lain adalah Merkuri (Hg), Timbal (Pb), Arsen (As), Kadmium (Cd), Krom (Cr), dan Nikel (Ni) (Suprabawati and Dwikora, 2016). Jenis logam berat utama diantara logam berat yang tersedia di perairan lingkungan Hidup merupakan logam $\mathrm{Cu}$. Logam $\mathrm{Cu}$ dapat masuk ke lingkungan dari kegiatan penambangan beberapa logam, dari unit industri yang membuat atau menggunakan logam $\mathrm{Cu}$ atau senyawa $\mathrm{Cu}$, dan dari sumber antropologi lainnya seperti tempat pembuangan limbah, air limbah domestik, pembakaran bahan bakar fosil dan limbah, produksi kayu dan produksi pupuk fosfat (Vilardi et al. 2017). Tembaga di dalam sistem darah dapat dihasilkan spesies oksigen bebas reaktif yang dapat merusak protein, lipid dan DNA (Brewer GJ,2007). Senyawa tembaga berlebih di tubuh juga mempengarui pada penuaan,skizofrenia, penyakit mental, sirosis kecil India, wilson dan penyakit alzheimer (Hossain et al. 2012).

\section{Daun Eceng Gondok}

Eceng gondok termasuk tanaman yang dapat dimanfaatkan sebagai bahan pembersih perairan dari limbah logam maupun menurunkan tingkat toksisitas yang terdapat dalam limbah dan mempunyai kemampuan menyerap unsur hara, senyawa organik dari air limbah dalam jumlah yang besar (Zaman dan Sutrisno, 2006).

Eceng gondok dapat menurunkan kadar BOD, partikel suspensi secara biokimiawi dan mampu menyerap logam-logam berat seperti $\mathrm{Cr}, \mathrm{Pb}, \mathrm{Hg}, \mathrm{Cd}, \mathrm{Cu}, \mathrm{Fe}, \mathrm{Mn}, \mathrm{Zn}$ dengan baik. Kemampuan menyerap logam persatuan berat kering eceng gondok lebih tinggi pada umur muda dari pada umur tua (Ahmad M.M, 2008).

Tabel 1. Hasil Penelitian

\begin{tabular}{lll}
\multicolumn{1}{c}{$\begin{array}{c}\text { Judul Paper, } \\
\text { tahun }\end{array}$} & \multicolumn{1}{c}{ Penulis } & \multicolumn{1}{c}{ Hasil Penelitian } \\
\hline Studi Kestimbangan & Chalid, 2008 & Adsorben campuran bentonit dan \\
Adsorpsi Merkuri & & enceng gondok yang tidak di \\
(II) Pada Biomassa & & aktivasi lebih sedikit daya serapnya \\
Daun Enceng & & dibandingkan dengan adsorben \\
\hline
\end{tabular}




\begin{tabular}{|c|c|}
\hline $\begin{array}{l}\text { Gondok (Eichornia } \\
\text { crassipes) }\end{array}$ & $\begin{array}{l}\text { yang di aktivasi. } \text { Penyerapan } \\
\text { maksimum }(0,987 \mathrm{mg} / \mathrm{g}) \text { terjadi } \\
\text { pada konsentrasi } 40 \mathrm{mg} / \mathrm{L} \text { pada } \\
\text { waktu kontak } 120 \text { menit dengan } \\
\text { kecepatan } 150 \mathrm{rpm} \text {. }\end{array}$ \\
\hline $\begin{array}{ll}\text { Efisiensi } & \text { Faisal, 2015 } \\
\text { Penyerapan Logam } & \\
\mathrm{Pb}^{2+} \text { Dengan } & \\
\text { Menggunakan } & \\
\text { Campuran Bentonit } & \\
\text { Dan Eceng Gondok } & \end{array}$ & $\begin{array}{l}\text { Enceng gondok yang di aktivasi } \\
\text { memiliki daya serap tinggi } \\
\text { dibandingkan dengan adsorben } \\
\text { yang tidak di aktivasi. }\end{array}$ \\
\hline $\begin{array}{ll}\text { Adsorpsi Logam } & \text { Rahmadani, } 2018 \\
\text { Kromium (Cr) Pada } & \\
\text { Limbah Cair Usaha } & \\
\text { Sablon } & \\
\text { Menggunakan } & \\
\text { Biomassa Daun } \\
\text { Eceng Gondok } \\
\text { (Eichornia } \\
\text { crassipes) }\end{array}$ & $\begin{array}{l}\text { Waktu kontak optimum yang } \\
\text { dibutuhkan oleh biomassa daun } \\
\text { eceng gondok untuk mengadsorpsi } \\
\text { ion logam kromium adalah } 150 \\
\text { menit. } \\
\text { Berat biomassa optimum yang } \\
\text { dibutuhkan untuk mengadsorpsi ion } \\
\text { logam kromium adalah } 1 \text { gram. }\end{array}$ \\
\hline
\end{tabular}

\section{PENUTUP}

Daun eceng gondok dapat dimanfaatkan sebagai adsorben karbon aktif dalam menyisihkan logam berat pada limbah cair sablon. Dalam penelitian sebelumnya adsorben enceng gondok yang tidak di aktivasi lebih sedikit daya serapnya dibandingkan dengan adsorben yang di aktivasi..

\section{DAFTAR PUSTAKA}

Al-Ayubi, Mochamad Chalid. "Studi Kestimbangan Adsorpsi Merkuri (II) Pada Biomassa Daun Enceng Gondok (Eichornia crassipes)", Skripsi (2008), h. 1-69.

Emelda, Lisanti, Putri,Suhardini Martiana and Ginting ,Simparmin Br.. 2013. Pemanfaatan Zeolit Alam Teraktivasi untuk Adsorpsi Logam $\mathrm{Cr}^{3+}$. Jurusan Teknik Kimia, Fakultas Teknik, Universitas Lampung. Vol. 9, No. 4, Hlm. 166 - 172

DOI: http://dx.doi.org/10.23955/rkl.v9i4.1229

Faisal, $\mathrm{M}$ "Efisiensi Penyerapan Logam $\mathrm{Pb}^{2+}$ Dengan Menggunakan Campuran Bentonit Dan Eceng Gondok". Jurnal (2015). Vol 4, No.1.

Firdaus, Lutfi ,et al .2018. Adsorption of Textile Dye by Activated Carbon Made from Rice Straw and Palm Oil Midrib. Aceh Int. J. Sci. Technol., 6(1),1-7 DOI: 10.13170/aijst.6.1.5502

Darjito,Darjito, Purwonugroho Danar,and Ningsih ,Rumiati. 2014.The Adsorption of Cr(VI) Ions Using Chitosan-Alumina Adsorbent. J. Pure App. Chem. Res. 3 (2), 53-61

Julita, Elsa Try , Kamil, Idris Maxdoni.2018. Mathematical Model To Identify Heavy Metal In Irrigation Channel From Cicabe Final Disposal Site. Indonesia Journal. Volume 2, Number 1, Page 1 - 13,

DOI : $\underline{\text { Http://Dx.Doi.Org/10.25105/Urbanenvirotech.V2i1.3530 }}$

Hossain,M. A., Ngo, H. Hao, W. S. Guo and Nguyen,T. V.. 2012. Removal of Copper from Water by Adsorption onto Banana Peel as Bioadsorbent. Int. J. of GEOMATE, Vol. 2, No. 2 (Sl. No. 4), pp. 227-234 
M. Hadiwidodo. 2012. Penggunaan Abu Sekam Padi Sebagai Adsorben Dalam Pengolahan Air Limbah Yang Mengandung Logam Cu," Teknik, vol. 29, no. 1, pp. 55-63 DOI: https://doi.org/10.14710/teknik.v29i1.1912

Rahmadani, 2018. "Adsorpsi Logam Kromium (Cr) Pada Limbah Cair Usaha Sablon Menggunakan Biomassa Daun Eceng Gondok (Eichornia crassipes)" Skripsi (2008).

Syauqiah, Isna. et al. 2011. Analisis Variasi Waktu dan Kecepatan Pengaduk Pada Proses Adsorpsi Limbah Logam Berat Dengan Arang Aktif. vol 12, no 1, DOI: http://dx.doi.org/10.20527/infotek.v12i1.1773

Zaman, Badrus dan Sutrisno, Endro, "Kemampuan Penyerapan Eceng Gondok (Eichornia crassipes) Terhadap Amoniak dalam Limbah Rumah Sakit Berdasarkan Umur dan Lama Kontak (Studi Kasus: RS. Panti Wilasa, Semarang)", Jurnal Presipitasi, Vol.1, No. 1 (2006), h. 49-54. 